\title{
Time and Distance Overcome
}

"Of what use is such an invention?" The New York World asked shortly after Alexander Graham Bell first demonstrated his telephone in 1876. The world was not waiting for the telephone.

Bell's financial backers asked him not to work on his new invention anymore because it seemed too dubious an investment. The idea on which the telephone depended - the idea that every home in the country could be connected with a vast network of wires suspended from poles set an average of one hundred feet apart-seemed far more unlikely than the idea that the human voice could be transmitted through a wire.

Even now it is an impossible idea, that we are all connected, all of us.

"At the present time we have a perfect network of gas pipes and water pipes throughout our large cities," Bell wrote to his business partners, in defense of his idea. "We have main pipes laid under the streets communicating by side pipes with the various dwellings.... In a similar manner it is conceivable that cables of telephone wires could be laid under ground, or suspended overhead, communicating by branch wires with private dwellings, counting houses, shops, manufactories, etc., uniting them through the main cable...."

Imagine the mind that could imagine this. That could see us all connected through one branching cable. The mind of a man who wanted to invent, more than the telephone, a machine that would allow the deaf to hear.

For a short time, the telephone was little more than a novelty. For twenty-five cents you could see it demonstrated by Bell himself, in a church, along with some singing and recitations by local talent. From a mile away, Bell would receive a call from "the invisible $\mathrm{Mr}$. Watson." Then the telephone became a plaything of the rich. A 
Boston banker paid for a private line between his office and his home so that he could let his family know exactly when he would be home for dinner.

Mark Twain was among the first to own a telephone, but he wasn't completely taken with it. "The human voice carries entirely too far as it is," he remarked.

By 1889, The New York Times was reporting a "War on Telephone Poles." Wherever telephone companies were erecting poles, homeowners and business owners were sawing them down, or defending their sidewalks with rifles.

In Red Bank, New Jersey property owners threatened to tar and feather the workers putting up telephone poles. One judge granted a group of homeowners an injunction to prevent the telephone company from erecting any new poles. Another judge found that a man who had cut down a pole because it was "obnoxious" was not guilty of malicious mischief.

Telephone poles, newspaper editorials complained, were an urban blight. The poles carried a wire for each telephone-sometimes hundreds of wires. And in some places there were also telegraph wires, power lines, and trolley cables. The sky was filled with wires.

The War on Telephone Poles was fueled, in part, by that terribly American concern for private property and a reluctance to surrender it to a shared utility. And then there was a fierce sense of aesthetics, an obsession with purity, a dislike for the way the poles and wires marred a landscape that those other new inventions, skyscrapers and barbed wire, were just beginning to complicate. And then perhaps there was also a fear that distance, as it had always been known and measured, was collapsing.

The city council in Sioux Falls, South Dakota ordered policemen to cut down all the telephone poles in town. And the Mayor of Oshkosh, Wisconsin ordered the police chief and the fire department to chop down the telephone poles there. Only one pole was chopped down before the telephone men climbed all the poles 
along the line, preventing any more chopping. Soon, Bell Telephone Company began stationing a man at the top of each pole as soon as it had been set, until enough poles had been set to string a wire between them, at which point it became a misdemeanor to interfere with the poles. Even so, a constable cut down two poles holding forty or fifty wires. And a homeowner sawed down a recently wired pole then fled from police. The owner of a cannery ordered his workers to throw dirt back into the hole the telephone company was digging in front of his building. His men threw the dirt back in as fast as the telephone workers could dig it out. Then he sent out a team with a load of stones to dump into the hole. Eventually, the pole was erected on the other side of the street.

Despite the War on Telephone Poles, it would take only four years after Bell's first public demonstration of the telephone for every town of over 10,000 people to be wired, although many towns were wired only to themselves. And by the turn of the century, there were more telephones than bathtubs in America.

"Time and dist. overcome," read an early advertisement for the telephone. Rutherford B. Hayes pronounced the installation of a telephone in the White House "one of the greatest events since creation." The telephone, Thomas Edison declared, "annihilated time and space, and brought the human family in closer touch."

In 1898, in Lake Comorant, Mississippi, a black man was hanged from a telephone pole. And in Weir City, Kansas. And in Brook Haven, Mississippi. And in Tulsa, where the hanged man was riddled with bullets. In Pittsburg, Kansas, a black man's throat was slit and his dead body was strung up on a telephone pole. Two black men were hanged from a telephone pole in Lewisburg, West Virginia. And two in Hempstead, Texas, where one man was dragged out of the courtroom by a mob and another was dragged out of jail.

A black man was hanged from a telephone pole in Belleville, Illinois, where a fire was set at the base of the pole and the man was cut 
down half-alive, covered in coal oil, and burned. While his body was burning, the mob beat it with clubs and nearly cut it to pieces.

Lynching, the first scholar of the subject determined, is an American invention. Lynching from bridges, from arches, from trees standing alone in fields, from trees in front of the county courthouse, from trees used as public billboards, from trees barely able to support the weight of a man, from telephone poles, from street lamps, and from poles erected for that purpose. From the middle of the nineteenth century to the middle of the twentieth century black men were lynched for crimes real and imagined, for "disputing with a white man," for "unpopularity," for "asking a white woman in marriage," for "peeping in a window."

The children's game of "telephone" depends on the fact that a message passed quietly from one ear to another to another will get distorted at some point along the line.

In Pine Bluff, Arkansas a black man charged with kicking a white girl was hanged from a telephone pole. In Long View, Texas a black man accused of attacking a white woman was hanged from a telephone pole. In Greenville, Mississippi a black man accused of attacking a white telephone operator was hanged from a telephone pole. "The negro only asked time to pray." In Purcell, Oklahoma a black man accused of attacking a white woman was tied to a telephone pole and burned. "Men and women in automobiles stood up to watch him die."

The poles, of course, were not to blame. It was only coincidence that they became convenient as gallows, because they were tall and straight, with a crossbar, and because they stood in public places. And it was only coincidence that the telephone pole so closely resembled a crucifix.

Early telephone calls were full of noise. "Such a jangle of meaningless noises had never been heard by human ears," Herbert Casson wrote in his 1910 History of the Telephone. "There were the rustling of leaves, the croaking of frogs, the hissing of steam, the flapping of 
birds' wings.... There were spluttering and bubbling, jerking and rasping, whistling and screaming."

In Shreveport, a black man charged with attacking a white girl was hanged from a telephone pole. "A knife was left sticking in the body." In Cumming, Georgia a black man accused of assaulting a white girl was shot repeatedly then hanged from a telephone pole. In Waco, Texas a black man convicted of killing a white woman was taken from the courtroom by a mob and burned, then his charred body was hung from a telephone pole.

A postcard was made from the photo of a burned man hanging from a telephone pole in Texas, his legs broken off below the knee and his arms curled up and blackened. Postcards of lynchings were sent out as greetings and warnings until 1908, when the Postmaster General declared them unmailable. "This is the barbecue we had last night," reads one.

"If we are to die," W.E.B. Du Bois wrote in 1911, "in God's name let us not perish like bales of hay." And "if we must die," Claude McKay wrote ten years later, "let it not be like hogs...."

In Danville, Illinois a black man was hanged from a telephone pole, cut down, burned, shot, and stoned with bricks. "At first the negro was defiant," The New York Times reported, "but just before he was hanged he begged hard for his life."

In the photographs, the bodies of the men lynched from telephone poles are silhouetted against the sky. Sometimes two men to a pole, hanging above the buildings of a town. Sometimes three. They hung like flags in still air.

In Cumberland, Maryland a mob used a telephone pole as a battering ram to break into the jail where a black man charged with the murder of a policeman was being held. They kicked him to death then fired twenty shots into his head. They wanted to burn his body, but a minister asked them not to. 
The lynchings happened everywhere, all over the United States. From shortly before the invention of the telephone to long after the first trans-Atlantic call. More in the South, and more in rural areas. In the cities and in the North there were race riots.

Riots in Cincinnati, New Orleans, Memphis, New York, Atlanta, Philadelphia, Houston....

During the race riots that destroyed the black section of Springfield, Ohio a black man was shot and hanged from a telephone pole.

During the race riots that set fire to East St. Louis and forced five hundred black people to flee their homes, a black man was hanged from a telephone pole. The rope broke and his body fell into the gutter. "Negros are lying in the gutters every few feet in some places," read the newspaper account.

In 1921, the year before Bell died, four companies of the National Guard were called out to end a race war in Tulsa that began when a white woman accused a black man of rape. Bell had lived to complete the first call from New York to San Francisco, which required 14,000 miles of copper wire and 130,000 telephone poles.

My grandfather was a lineman. He broke his back when a telephone pole fell. "Smashed him onto the road," my father says.

When I was young, I believed that the arc and swoop of telephone wires along the roadways were beautiful. I believed that the telephone poles, with their glass transformers catching the evening sun, were glorious. I believed my father when he said, "My dad could raise a pole by himself." And I believed that the telephone itself was a miracle.

Now, I tell my sister, these poles, these wires do not look the same to me. Nothing is innocent, my sister reminds me. But nothing, I would like to think, remains unrepentant. 
One summer, heavy rains fell in Nebraska and some green telephone poles grew small leafy branches.

\begin{abstract}
A Note on "Time and Distance Overcome"
I began my research for this essay by searching for every instance of the phrase "telephone pole" in the New York Times from 1880 to 1920, which resulted in 370 articles. As I read through these articles, starting with the oldest and working forward in time, I was not prepared to discover, in the process, a litany of lynchings. I had not intended to write an essay about lynching, but I found that, given what my research was yielding, I could not avoid it. After reading an article headlined "Colored Scoundrel Lynched," and then another headlined "Mississippi Negro Lynched," and then another headlined "Texas Negro Lynched," I searched for every instance of the word "lynched" in the New York Times from 1880 to 1920, which resulted in 2,354 articles.

I refer, in this essay, to the first scholar of lynching, meaning James E. Cutler, author of the 1905 book Lynch-Law, in which he writes, on the first page, "lynching is a criminal practice which is peculiar to the United States." This is debatable, of course, and very possibly not true, but there is good evidence that the Italian Antonio Meucci invented a telephone years before Bell began working on his device, so as long as we are going to lay claim to one invention, we might as well take responsibility for the other.
\end{abstract}

